\title{
Plagiarism in five universities in Mozambique: Magnitude, detection techniques, and control measures
}

Peter E Coughlin

\author{
Correspondence: \\ econpolicy@gmail.com \\ EconPolicy Research Group, Ltd, \\ Maputo, Mozambique
}

\begin{abstract}
Hugely facilitated by the Internet, plagiarism by students threatens educational quality and professional ethics worldwide. Plagiarism reduces learning and is correlated with increased fraud and inefficiency on the job, thus lessening competitiveness and hampering development.

In this context, the present research examines 48 licenciatura theses and 102 masters theses from five of Mozambique's largest universities. Of the 150 theses, $75 \%$ contained significant plagiarism (>100 word equivalents) and 39\%, very much (>500 word equivalents). Significant plagiarism was detected in both licenciatura and masters theses. By using both Turnitin and Urkund to identify potentially plagiarized passages, professionally verifying whether those passages contain plagiarism, and, if confirmed, counting the words involved, the study presents a new method for classifying the quantity and significance of plagiarism. The use of two text-similarity-recognition programs also improved the rate of detection and, in some theses, significantly increased the classification of the gravity of the plagiarism encountered. Based on a broad review of the literature, the article argues that, to combat wide-scale plagiarism, academic institutions need to cultivate a consensus among faculty and students about the definition and types of plagiarism, the appropriate penalties, and the paramount professional and economic need to nurture professional ethics. However, to achieve even partial success requires significant involvement by administrators, faculty, students and student leaders guided by a holistic strategy using technological, pedagogical, administrative and legal components to prevent and detect plagiarism and then reeducate or discipline students caught plagiarizing.
\end{abstract}

Keywords: Plagiarism; Cheating; Paraphrase; Plagiarism detection; Academic fraud; Academic integrity; Honour code; Mozambique

\section{Introduction}

Hugely facilitated by computers and the Internet, plagiarism by students threatens educational quality and professional ethics worldwide though those same technologies can be used to teach correct practices and detect transgressions. Spanning continents, including Africa, student plagiarism affects teaching and learning across the entire gamut of arts and science courses, and-if it becomes habitual-is associated later with unethical professional behavior detrimental to governmental and economic efficiency. This association between academic and work ethics adds urgency to the need to devise

\section{Springer}


holistic strategies using technological, pedagogical, administrative and legal measures to prevent or detect plagiarism and then reeducate or discipline infractors. However, to succeed even partially, such a concerted and integrated effort requires academic authorities to have analytical clarity and firm determination to confront likely technological and sociocultural obstacles, perhaps including subtle or even open resistance within their institutions.

In this context, the present report investigates the types, frequency and quantity of plagiarism in licenciatura and masters monographs and theses in five large Mozambican universities. Then, after a review of the international literature about students' motives, the factors facilitating or discouraging plagiarism, and what some universities have done to reduce its incidence, the study recommends a holistic set of measures to train, motivate and discipline students better.

\section{The global context}

Numerous studies confirm that many students plagiarize-nearly everywhere. Plagiarism is widely condemned by academics and other professionals as "an unacceptable form of misbehavior and a violation against other researchers" and, for gross offences, attracts severe penalties (European Science Foundation \& All European Academies 2011, p. 8). Nevertheless, when asked to classify samples of plagiarized texts, both students and professors (including lecturers) express diverse opinions especially about how grievous each case is or, sometimes, about whether a specific text even contains plagiarism at all (Pincus and Schmelkin 2003, p. 198). This indicates the need for clear definitions, consensus building, and consistent interpretations to quantify, understand and combat plagiarism, a global reality with many motives and educational, individual and national consequences.

\section{Plagiarism: definition, consensus building, and consistent interpretation Definition and symptoms}

Plagiarism is presenting as your own another person's words, ideas, data, artwork or designs-unless considered common knowledge-without referencing the true author. In written works, this happens in three forms: (i) verbatim (word-for-word) copies without quotation marks and/or references (ii) paraphrases without references and (iii) "use of another author's unique ideas, data or evidence (though not their words) without reference to the source" (Coughlin, 2013, p. 18). From these basic types are derived many, often overlapping subtypes and combinations. For example, mosaic plagiarism occurs when the work uses "bits and pieces from a source (or several sources), changing a few words here and there without either adequately paraphrasing or quoting directly" (Harvard College Writing Program 2013).

Copyright issues aside, reuse of one's own work, especially if the source is cited and the target audience is largely different than that for the original work, is usually considered acceptable republication. However, if the target audience is mostly the same (e.g., via another scientific journal in the same discipline) or if the source is not acknowledged, the reuse gains a less respectable name, self-plagiarism, especially when large tracts of recycled text are involved (Collberg \& Kobourov 2005, p. 92 and 94; Bretag \& Mahmud, 2009, p. 193; Andreescu 2013, p. 775 and 796). 
Another problem occurring in tandem with plagiarism is the abuse of secondary citations, a frequent practice among students and even some professionals. To avoid errors, accepted professional practice insists on use of the primary source of a citation or data except when access is impossible or extremely difficult. Even in this latter case, one must reference both the primary and secondary sources so readers can judge the wisdom of relying on the latter's accuracy. In this regard, students frequently commit three errors: (i) taking information and references from secondary sources though the primary source is easily available; (ii) referencing an unread (unavailable?) primary source without mentioning the secondary source where, in fact, they got the information; and (iii) erroneously referencing secondary sources as if they were the primary sources. In all three cases, a superficial review by a professor might conclude that the formal aspects of source referencing were obeyed whereas, in fact, essential information had been omitted (Pecorari 2006, p. 14 and 17).

\section{Gravity of the offense: perceptions, consensus building, and consistent interpretations}

To determine the gravity of plagiarism, purposeful deception is the central issue and, if proven, is widely condemned (Pecorari 2013: KL441-42). ${ }^{\text {a }}$ However, purposeful deception is often omitted from academic codes of behaviour to avoid creating a loophole for real plagiarists to allege unintentionality. Instead, intentionality is only considered when pondering which remedial or disciplinary measures to apply to a specific incident (Devlin 2006, p. 48; Pecorari 2013: KL445-46). As Standler (2012) argues, since "copyright infringement occurs without proof of intent by the infringer,... intent should also be irrelevant to determination of plagiarism" (p. 7).

Significant differences of opinion also arise when professors are requested to compare specific texts against their sources and judge whether plagiarism has occurred. For example, in a survey asking 152 professors from five universities in the New York-New Jersey metropolitan area and 49 from the Internet to classify six passages involving progressively worse plagiarism, none of "the paragraphs yielded 100\% agreement among respondents". The professors' criteria for determining plagiarism ranged from very lax to extremely rigorous (Roig 2001, p. 313).

Students too have divergent perceptions about what and how serious plagiarism is. For example, in two New York colleges where 316 undergraduate students were requested to judge 10 paragraphs, 76\% "correctly identified the two paraphrased versions of the original", but approximately $50 \%$ incorrectly identified "six of the plagiarized versions of the paragraph" as not having been plagiarized (Roig 1997, p. 117). Often, students admit to not even having a clear notion of what plagiarism is (Michalska 2012, p. 8). Various studies also confirm that most students do not deem plagiarism a serious offence (McCabe et al. 2012: KL832; Pupovac et al. 2010).

Professors not only hold diverse opinions about what constitutes plagiarism but also react in widely different ways when discovering it in a student's work. Typically, when considering how to respond, professors and administrators consider "intention, extent, and scale of the offence" but the penalties they recommend vary greatly for the same offence (Flint et al. 2006, p. 149; Carroll \& Appleton 2005). Moreover, faculty may be disinclined to cooperate with a university's regulations requiring central reporting of incidents of plagiarism, if they (i) consider "the offence ... as unintentional or caused by personal stress" (Paterson et al. 2003, p. 147), (ii) think the rules would impose 
unjustly severe penalties in a specific case (Pincus \& Schmelkin 2003, p. 208), (iii) feel the university would not "deal with the instances adequately" (Sutherland-Smith 2003 , p. 11), or (iv) deem "the misconduct investigations ... too cumbersome" and time-consuming (Standler 2012, p. 78).

The problem, therefore, is more than just obtaining a clear definition of plagiarism but also of building consensus and getting both students and professors to apply the definition and appropriate disciplinary or pedagogical measures in a reasonably consistent manner. For example, "to promote systematic and consistent decision-making" about plagiarism, Curtin University of Technology in Australia identified "four dimensions or criteria: experience, nature, extent and intent" (Yeo \& Chien 2007, p. 190). In the UK, due to growing concern about "inconsistency in the application of penalties for student plagiarism within higher education", "the Higher Education Academy funded the Academic Misconduct Benchmarking Research Project, which confirmed vast variation between different institutions in the penalties available for student plagiarism" (Tennant \& Rowell 2010, p. 3). After requesting 104 academics to identify important factors for judging the seriousness of and appropriate disciplinary and/or pedagogical response for hypothetical cases ranging from minor to major plagiarism, the project designed a "benchmark tariff for application of penalties for student plagiarism in higher education" (Tennant \& Rowell 2010: 5-8 and 13). Though the system never gained widespread acceptance, it "foster[ed] the notion that criteria can be defined and applied for judging the seriousness of an offense" (Weber-Wulff 2014, p. 148).

\section{Measuring plagiarism by frequency}

To measure plagiarism, most studies ask students whether they or their colleagues plagiarize. ${ }^{\mathrm{b}}$ This, however, risks seriously underestimating the true values since some respondents may be reticent to admit to socially disapproved behaviour (Jann et al. 2012, p. 33).

Credibility is further strained by the often sizeable gulf between self-reported plagiarism by individual students and their perceptions of what their peers are doing. For instance, a mere $8 \%$ of Scanlon and Neumann's [2002, p. 380] sample admitted to copying a text from the Internet without citation, but perceived that over $50 \%$ of their peers did so (Walker 2010, p. 2).

In another study of 698 undergraduates at eight colleges and universities in the US and an American university in the Middle East, 28.6\% admitted having plagiarized sometimes or very frequently whereas they thought that $91.1 \%$ of their colleagues plagiarized at least sometimes-a massive inconsistency (Scanlon \& Neumann 2002, p. 380). Though students often underreport their own plagiarism while averring higher rates of plagiarism among their colleagues, even those high rates sometimes underestimate reality. For example, among economic M.A. graduates and finalists in a Mozambican university, "30\% alleged that between $10 \%$ to $50 \%$ of the students plagiarize in their theses" whereas, in a random sample, all 21 of the selected theses contained plagiarized passages-a percentage far higher than what the respondents estimated (Coughlin, 2013, p. 13). With opinions and selfconfessions often underestimating the problem, "an accurate picture ... of student plagiarism can be obtained only through ... empirical measurement of plagiarism in 
student work, rather than ... [through] self-reports, perceptions or assumptions" (Walker 2010, p. 3). In other words, "investigate what students do, ... [not] what they say they do" (Karlins et al. 1988, p. 363). That is the focus and method of the present study.

\section{Plagiarism: an ubiquitous international problem with varying frequencies}

Despite variations between countries, institutions and the students at different academic levels, plagiarism is an enduring, grave and global problem (Teixeira \& Rocha 2010b, p. 663). Data spanning nearly four decades comparing academic fraud, including plagiarism, on multiple campuses in the US between 1963 and 2000, reveal that, except for a big increase in illicit collaboration on student assignments, "most of the rates of self-reported cheating at ... [non-honour-code] schools in the 1990s are roughly the same as or lower than the rates reported by Bowers [1964] at his no-code schools in the early 1990s" (McCabe et al. 2012: KL905 and KL983).

Looking more narrowly at only plagiarism, numerous studies confirm that now-in the age of the Internet-the problem is worldwide (Table 1). Moreover, though all academic disciplines suffer significant plagiarism, science, technology, engineering and math may have somewhat higher rates than arts and humanities (Selwyn 2008, p. 469-70; McCullough \& Holmberg 2005, p. 439; Pecorari 2006).

Plagiarism is thus a ubiquitous multiform problem confronting educational institutions worldwide. But how serious is the problem? What are the academic, scientific, social and economic implications?

\section{Who loses? Who gains?}

When students plagiarize, their educational institutions and instructors underachieve and, if cheating is rampant, risk their reputations (iThenicate 2012). Academic fraud is especially perverse if grades are determined by a subtle or explicit curve because, with that, students who stick to correct practices are penalized and, upon entering the job market, may have to compete against graduates with diplomas and high grades but less knowledge and ability (Todd-Mancillas et al. 1987, p. 5). The cheats also jeopardize

Table 1 Selected studies of plagiarism from four continents

\begin{tabular}{|c|c|c|c|c|}
\hline $\begin{array}{l}\text { Country and } \\
\text { universities }\end{array}$ & $\begin{array}{l}\% \text { of students } \\
\text { admitting } \\
\text { plagiarism }\end{array}$ & Students sampled & Universities & Sources \\
\hline Portugal & $42 \%$ & 5,403 & numerous & Teixeira (2011, p. 2) \\
\hline \multirow[t]{2}{*}{ US and Canada } & $33 \%$ & graduate business & \multirow[t]{2}{*}{54} & \multirow{2}{*}{$\begin{array}{l}\text { McCabe et al. (2006, } \\
\text { p. 300) }\end{array}$} \\
\hline & $22 \%$ & non-business & & \\
\hline Australia & $81 \%$ & 954 & 4 & Marsden et al. $(2005$, p. 8) \\
\hline UK & Three-fifths & 1,222 undergraduates & numerous & Selwyn (2008, p. 465) \\
\hline \multirow[t]{2}{*}{ South Africa } & $80 \%$ & 150 undergraduates & U of Pretoria & Russouw (2005) \\
\hline & One-quarter & $\begin{array}{l}151 \text { first-year } \\
\text { geography }\end{array}$ & $\begin{array}{l}\text { U of KwaZulu- } \\
\text { Natal }\end{array}$ & Ellery (2008, p. 507) \\
\hline Botswana & $86 \%$ & 138 & U of Botswana & Batane (2010, p. 5-6) \\
\hline Egypt & $33 \%$ & 238 & 1 & $\begin{array}{l}\text { Nejati et al. (2011, } \\
\text { p. 284) }\end{array}$ \\
\hline
\end{tabular}


their own long-term future since, with little valid experience conducting and writing about research, they will rarely attain real innovativeness and profound, original insights useful for society.

Employers and the economy also suffer since such graduates have low skills and, sometimes, poor work ethics including outright thieving. For example, a study of 1,051 students on six campuses found "a high correlation between the frequency of cheating at college and the frequency of cheating at work" (Nonis \& Swift 2001, p. 75). In another study of $60 \mathrm{MBA}$ students, those "who engaged in behaviours considered severely dishonest during college were more likely to ... [do so] at work. Similarly, subjects who engaged in mildly dishonest behaviours (or no dishonest behaviour) during college were more likely" to continue that pattern at work (Sims 1993). Lawson (2004, p. 195) also confirmed a "very strong relationship between students' propensity to engage in unethical behaviour in an academic setting and their attitude toward such behavior in the business world".

\section{Research problem and methodology}

Given the gravity and high rates of plagiarism worldwide, are Mozambican university students different? How often do they plagiarize?

Methodologically, the study chose the educational institutions and theses, identified plagiarized passages, and categorized the types and amount of plagiarism in each thesis. Five large universities ${ }^{c}$ in Mozambique were chosen and, within these, the principal focus was on the arts and social science departments (e.g., economics, management, accounting, education, sociology and linguistics) though, due to scarcity, a few theses were selected from other disciplines in some institutions (Table 2). Masters theses were examined in three universities whereas licenciatura theses (including monographs) were analysed in two universities that had few or no masters theses. The theses were selected from those in the universities' main libraries or, in some cases, on the Internet or from a departmental library. For the Universidade Eduardo Mondlane's sociology, education and economics departments, all the MA theses available in the main library were selected. Elsewhere, the sample was drawn systematically from the available theses (Table 3). Selected theses partially scanned in the library were replaced if their digital versions were later found on the Internet.

Except for linguistics, the available theses did not include the full universe of theses approved during the study period (2001 to 2013) since graduates often failed to give the libraries copies of their theses. Thus, except for linguistics, the samples-even if randomly drawn-could never be a random sample of all theses in the selected departments. Nor can confidence intervals be estimated for the resulting statistics.

Table 2 Selected theses by discipline

\begin{tabular}{llllll}
\hline Discipline & Theses & Discipline & Theses & Discipline & Theses \\
\hline Education & 36 & Economics & 12 & Philosophy & 5 \\
Sports education & 9 & Linguistics & 20 & Informatics & 5 \\
Management & 35 & Law & 4 & Fishing resources & 7 \\
Accounting & 9 & Sociology & 6 & Medicine \& pharmacy & 2 \\
& & & & Total theses & 150 \\
\hline
\end{tabular}


Table 3 Selection methods for theses and end-of-course monographs

\begin{tabular}{|c|c|c|c|c|c|}
\hline \multirow[t]{2}{*}{ Institution } & \multirow{2}{*}{$\begin{array}{l}\text { Total } \\
\text { theses }\end{array}$} & \multicolumn{2}{|c|}{ Full theses } & \multicolumn{2}{|c|}{ Partial copies } \\
\hline & & $\mathrm{n}^{\circ}$ & Selection method & $\mathrm{n}^{\circ}$ & Selection method \\
\hline$\overline{U P}$ & 24 & 7 & Selected by librarian & 17 & Systematic sample ${ }^{2}$ \\
\hline ISCTEM & 23 & 0 & n.a. & 23 & Systematic sample \\
\hline UPol/ISPU & 21 & 3 & Substitution from Internet ${ }^{1}$ & 18 & Systematic sample \\
\hline USTM & 25 & 22 & $\begin{array}{l}\text { Systematic sample from } \\
\text { subset of library's recent CDs }\end{array}$ & 3 & Systematic sample ${ }^{3}$ \\
\hline UEM linguistics & 20 & 1 & Substitution from Internet ${ }^{1}$ & 19 & $\begin{array}{l}\text { Systematic sample from } \\
\text { dept. archives }\end{array}$ \\
\hline UEM economics & 12 & 1 & Full OCR from main library & 11 & $\begin{array}{l}\text { Entire collection from } \\
\text { main library }\end{array}$ \\
\hline UEM education & 21 & 2 & Substitution from Internet ${ }^{1}$ & 19 & $\begin{array}{l}\text { Entire collection from } \\
\text { main library }\end{array}$ \\
\hline UEM sociology & 4 & 0 & n.a. & 4 & $\begin{array}{l}\text { Entire collection from } \\
\text { main library }\end{array}$ \\
\hline Total & 150 & 33 & n.a. & 117 & n.a. \\
\hline
\end{tabular}

${ }^{1}$ full theses or end-of-course monographs found on the Internet and substituted for the originally selected partial copies ${ }^{2}$ For systematic sampling, the number of available theses was divided by the target number of theses $( \pm 20)$ to calculate the desired selection interval, S (e.g., every third thesis); the first thesis to be chosen was randomly selected within that value; and then every $S^{\text {th }}$ thesis was randomly selected. Upon examination, many theses were outside the target years or from other institutions and were, hence, substituted.

${ }^{3}$ After selecting a few hardbound theses systematically, the librarian informed us that many theses were available on CDs. Thereafter the selections came from these.

The 150 chosen theses or end-of-course monographs comprised 33 digital copies and 117 bound copies. From the bound copies, selected pages from the introduction, identification of the problem, literature review, and often a portion of the analysis were photographed, converted into digital characters in an MS Word file, and spell checked. Of the theses, 138 were inspected by both TurnItIn and Urkund, two highly rated text-similarity-recognition (TSR) programs (Weber-Wulff et al. 2013, p. 9), whereas the 12 M.A. end-of-course monographs from UEM's economics department were only inspected by Urkund.

TurnItIn checks for similarities with texts in the original language and, upon request, with those in English though the latter search rarely revealed additional similarities. Urkund does not check for plagiarized texts translated from English. As a workaround, one must translate the text to English and then check for additional similarities. Curiously, the TSR programs never reported any similarities with Spanish-language documents, which would be easy sources for Portuguese speaking plagiarists. Since important books and articles are often translated into Spanish, the programs' failure to spot such similarities seems anomalous unless-directly or indirectly, purposely or inadvertently-their search algorithms excluded this language.

TSR programs generate an overall "similarity" percentage for each submitted work though similarity does not necessarily mean plagiarism. Confirmation of plagiarism requires professional analysis. For example, if a quotation is indented from the left margin and has no quotation marks, it is included in the similarity statistic though indenting an extended quotation, referencing the source and omitting the quotation marks is standard academic practice, not plagiarism.

As for paraphrases, TSR programs often spot the possible sources when just some words are switched out but may fail when confronted with numerous morpholexiconic, structural or semantic changes (Barrón-Cedeño et al. 2012, p. 917 and 920). However, 
for the sampled theses, whenever the programs spotted a sentence or paragraph with strong similarities, it was usually easy to confirm or disconfirm the text as plagiarism by looking for indenting, slightly misplaced quotation marks, or a reference to the source and by comparing the density, volume and sequence of the "original" against the student's text. After this scrutiny, ambiguous cases were rare and, to be conservative, always excluded from the count of plagiarized words.

Each thesis was classified by the types and extent of the plagiarism identified. To improve replicability and comparability, the classification is quantitative. Thus, in thesis $i$, the total number of plagiarized words was counted in:

a. passages copied verbatim or paraphrased with neither references nor quotation marks or their equivalent $\left(\mathrm{PRQ}_{\mathrm{i}}\right)$; and

b. passages with references but without the required quotation marks $\left(\mathrm{PQ}_{\mathrm{i}}\right)$.

To classify the gravity of the plagiarism, the overall plagiarism index $\left(\mathrm{PI}_{\mathrm{i}}\right)$ is defined as the number of words plagiarized with neither references nor quotation marks (or equivalent) plus $50 \%$ of the words plagiarized with references but without quotation marks:

$$
\mathrm{PI}_{\mathrm{i}}=\mathrm{PRQ}_{\mathrm{i}}+0.5 * \mathrm{PQ}_{\mathrm{i}}
$$

Since an academic or other professional (or, these days, even a politician) who plagiarizes 100 words $(\approx$ a half a page) would, if caught, likely be in trouble and, if they plagiarized 500 or more words ( $\approx$ two and a half pages), would, if caught, rarely escape grave repercussions, "significant" plagiarism was defined as 100 to 199 word-equivalents, "much" plagiarism as 200 to 499 word-equivalents, and "very much" as 500 or more (Table 4). The likelihood of grave professional repercussions is why "very much" plagiarism was set as 500 or more word-equivalents.

Of the plagiarized words counted in all theses, $49 \%$ were verbatim or paraphrased (with portions that were copied verbatim) and lacked both references and required quotation marks whereas $51 \%$ had references but lacked quotation marks. Thus, on average, a student's work classified as containing "very much" plagiarism possessed at least 335 words of direct plagiarism and 335 words with references but lacking quotation marks, i.e., in total, nearly three pages-well enough to inspire serious accusations and, perhaps, jeopardise an author's job if done in a professional paper.

Table 4 Classification of plagiarism by total word-equivalents

\begin{tabular}{ll}
\hline Classification & Plagiarized word-equivalents \\
\hline None & 0 \\
Very little & $\leq 50$ \\
Little & $50 \leq 100$ \\
Significant & $100 \leq 200$ \\
Much & $200 \leq 500$ \\
Very much & $>500$ \\
\hline
\end{tabular}


Table 5 Plagiarism revealed in a sample of 150 theses in $\mathbf{5}$ universities in Mozambique

\begin{tabular}{|c|c|c|c|c|c|c|c|c|c|c|c|}
\hline \multirow[t]{3}{*}{ Institution } & \multirow{3}{*}{$\begin{array}{l}\text { Type } \\
\text { of } \\
\text { thesis }\end{array}$} & \multirow{3}{*}{$\begin{array}{l}\mathrm{n}^{\circ} \text { of } \\
\text { theses }\end{array}$} & \multicolumn{7}{|c|}{ Severity of the plagiarism* } & \multirow{3}{*}{$\begin{array}{l}\text { Memo: } \% \text { with } \\
\text { significant, much } \\
\text { or very much } \\
\text { plagiarism } \\
\text { A + B + C }\end{array}$} & \multirow{3}{*}{$\begin{array}{c}\text { Memo: \% with } \\
\text { none or very little } \\
\text { plagiarism } \\
\text { E + F }\end{array}$} \\
\hline & & & Very much & Much & Significant & Little & Very little & None & Total & & \\
\hline & & & A & B & C & D & $\mathrm{E}$ & $F$ & G & & \\
\hline$\overline{U P}$ & Masters & 24 & $33 \%$ & $33 \%$ & $17 \%$ & $4 \%$ & $8 \%$ & $4 \%$ & $100 \%$ & $83 \%$ & $13 \%$ \\
\hline ISPU & Masters & 21 & $38 \%$ & $19 \%$ & $14 \%$ & $5 \%$ & $14 \%$ & $10 \%$ & $100 \%$ & $71 \%$ & $24 \%$ \\
\hline ISCTEM & Lic. & 23 & $17 \%$ & $35 \%$ & $13 \%$ & $17 \%$ & $9 \%$ & $9 \%$ & $100 \%$ & $65 \%$ & $17 \%$ \\
\hline USTM & Lic. & 25 & $72 \%$ & $20 \%$ & $8 \%$ & $0 \%$ & $0 \%$ & $0 \%$ & $100 \%$ & $100 \%$ & $0 \%$ \\
\hline UEM linguistics & Masters & 20 & $15 \%$ & $5 \%$ & $25 \%$ & $5 \%$ & $15 \%$ & $35 \%$ & $100 \%$ & $45 \%$ & $50 \%$ \\
\hline UEM education & Masters & 21 & $33 \%$ & $29 \%$ & $14 \%$ & $19 \%$ & $5 \%$ & $0 \%$ & $100 \%$ & $76 \%$ & $5 \%$ \\
\hline UEM sociology & Masters & 4 & $100 \%$ & $0 \%$ & $0 \%$ & $0 \%$ & $0 \%$ & $0 \%$ & $100 \%$ & $100 \%$ & $0 \%$ \\
\hline UEM economics** & Masters & 12 & $38 \%$ & $23 \%$ & $14 \%$ & $8 \%$ & $8 \%$ & $9 \%$ & $100 \%$ & $75 \%$ & $8 \%$ \\
\hline Weighted average (all years) & $\%$ & & $39 \%$ & $22 \%$ & $15 \%$ & $9 \%$ & $7 \%$ & $9 \%$ & $100 \%$ & $75 \%$ & $16 \%$ \\
\hline Grand Total & $n^{\circ}$ & 150 & 58 & 33 & 22 & 13 & 11 & 13 & 150 & & \\
\hline years $<2008$ & & 25 & $28 \%$ & $40 \%$ & $12 \%$ & $12 \%$ & $4 \%$ & $4 \%$ & $100 \%$ & $80 \%$ & $8 \%$ \\
\hline $2008 \leq$ years $\leq 2013$ & & 125 & $41 \%$ & $18 \%$ & $15 \%$ & $8 \%$ & $8 \%$ & $10 \%$ & $100 \%$ & $74 \%$ & $18 \%$ \\
\hline Licenciaturas & & 48 & $46 \%$ & $27 \%$ & $10 \%$ & $8 \%$ & $4 \%$ & $4 \%$ & $100 \%$ & $83 \%$ & $8 \%$ \\
\hline Masters & & 102 & $35 \%$ & $20 \%$ & $17 \%$ & $9 \%$ & $9 \%$ & $11 \%$ & $100 \%$ & $72 \%$ & $20 \%$ \\
\hline
\end{tabular}

*For definitions, see Table 3 .

**The 12 monographs from UEM's economics faculty were examined only by Urkund thus yielding a downward bias since Turnltln might have spotted additional problems. The monographs examined here are by different authors than those evaluated in Coughlin (2013) though the results are quite similar, i.e., $91 \%$ vs $100 \%$ containing at least some plagiarism. 


\section{Research results}

Overall, $75 \%$ of the 150 sampled theses and monographs in the five universities contained significant, much or very much plagiarism. Only $16 \%$ had very little or no plagiarism (Table 5). Of the masters theses in UEM's department of linguistics, $45 \%$ contained significant, much or very much plagiarism as against $65 \%$ or more in all other departments or universities. Albeit from different institutions, at least $65 \%$ of both the licenciatura and masters theses contained significant or worse plagiarism (Table 5).

Plagiarism was measured by (i) an initial examination by TurnItIn, (ii) a complementary examination by Urkund whenever its similarity statistic was at least $5 \%$ points higher than TurnItIn's (33 cases), unless the latter's results had already found "very much" plagiarism (13 cases), and (iii) translation and re-evaluation in English by Urkund of the OCR portions of two highly mathematical econometric monographs with low similarity ratings despite strong signs of possible plagiarism. Four additional theses with smaller gaps between TurnItIn's and Urkund's detection rates were compared to confirm the adequacy of that $5 \%$ cut-off. In total, 24 theses were re-evaluated by the joint results of both programs. Of these, 19 contained additional plagiarized passages that worsened the classification, in some cases, very significantly. Whereas, by using TurnItIn alone, 70\% of 138 theses contained significant or worse plagiarism, the supplemental use of Urkund raised this to $75 \%$ (Tables 5 and 6). Three cases jumped from no detected plagiarism to "very much" and another went from "little" to "very much" (Figure 1). In other words, the use of TurnItIn alone would have granted a good bill of health to three highly infected theses and declared another as having sniffles instead of pneumonia.

Why these big oversights occurred was not analyzed. Though the similarity statistic can be nil or tiny for various reasons (e.g., a true reading, absence of the source in the database, an inadequate search algorithm, or technical sabotage by the plagiarist), whenever that statistic is very low, a second verification helps to guard against an erroneous report of cleanliness. This finding concurs with Gillam et al. (2010) analysis of possible techniques used to defeat TSR programs (p. 84).

Whether the software can check for similarities with foreign-language texts may also-albeit rarely-make the difference between spotting or missing significant plagiarism. For example, in one econometric thesis, Urkund found $2 \%$ similarities, which, after professional verification, yielded merely 26 truly plagiarized words. However, after Google translated the text to English, Urkund found an additional 6\% similarities containing many instances of real plagiarism, enough to change the thesis' rating from "very little" to "very much" plagiarism.

Table 6 Jump in the detected severity of plagiarism due to supplemental inspection by Urkund whenever it found $5 \%$ points more similarities than Turnltln

\begin{tabular}{lc}
\hline Jump in categories of severity & Number of cases \\
\hline 0 & 4 \\
1 & 10 \\
2 & 1 \\
3 & 4 \\
4 & 0 \\
Total cases & 19 \\
\hline
\end{tabular}




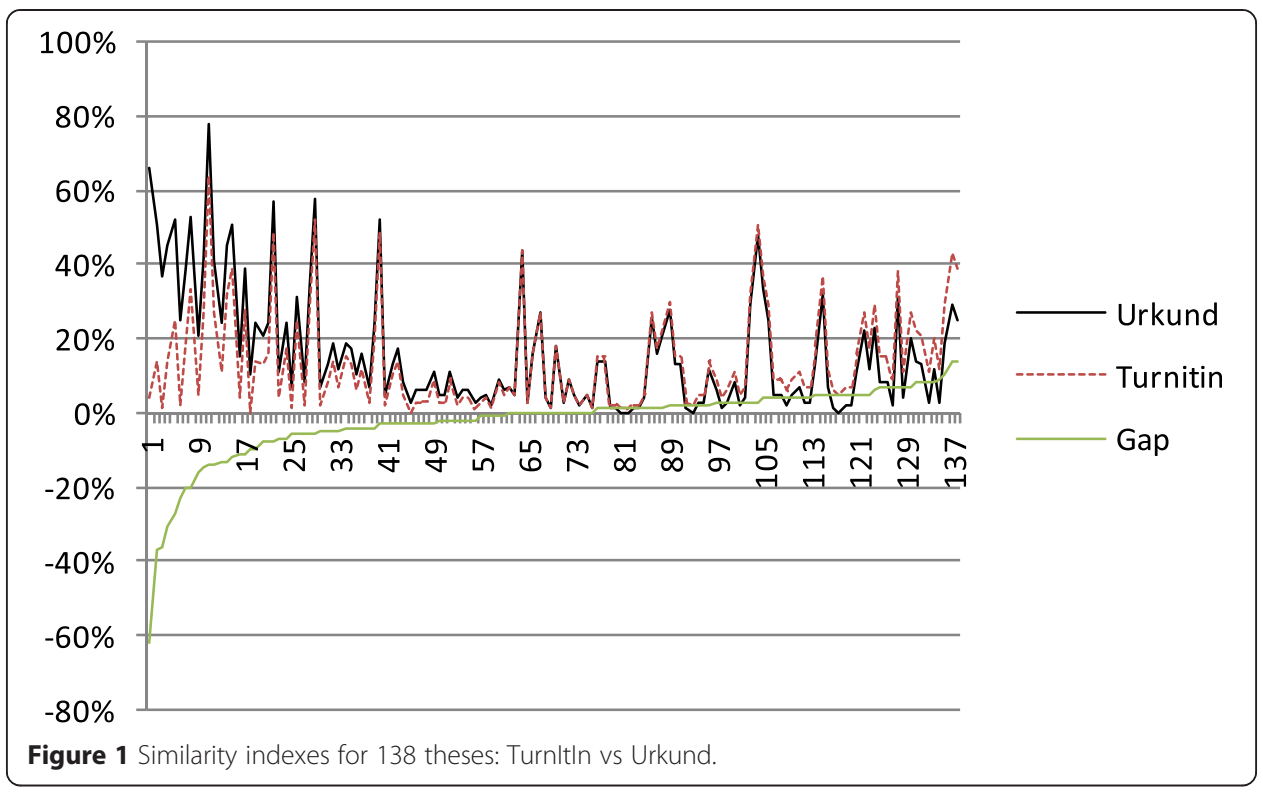

\section{Motives, facilitating factors, and preventive measures: global lessons}

Since, as elsewhere, many Mozambican university students plagiarize, sometimes extensively, how can educational institutions train and motivate them to produce academically correct original research and literature reviews and, thereby, acquire proper ethics, technical proficiency and more profound knowledge, all of great use later for professional achievement and national development? A good strategy requires understanding why and how students plagiarize and how the technical and socio-economic environment can facilitate or discourage academic fraud.

Though the present study did not ask student authors about their motives and circumstances, extensive research with fairly consistent findings from numerous countries recommends complementary measures to inspire learning and encourage correct practices.

\section{Motives and environmental influences}

Some students plagiarize for ignorance of professional ethics and proper citation techniques; others, to compensate for lack of good research and writing skills; and yet others, due to time pressures.

Though learning to write well and reference sources should begin in junior high or high school, many university students lack these skills. "Ineffective study skills [are also] associated with substandard academic performance, lack of academic integration, and the tendency to plagiarise" (Bennett 2005, p. 154). Poorly copied notes can also cause inadvertent plagiarism (Pecorari 2013: Ch. 1, KL642). Moreover, even students with these skills can succumb to the temptation of good grades with little effort, especially if detection is rare and punishment, slight or non-existent (Roig 1997, p. 121). Indeed, upon detecting academic fraud, teachers often ignore prescribed disciplinary procedures (Jendrek 1989, p. 402-3).

A student's decision to commit academic fraud, including plagiarism, is greatly influenced by approval or disapproval by peers and observation of their good or bad 
behaviour. Consequently, the failure to detect it and re-educate or discipline perpetrators nurtures a lax, tolerant ambience tempting additional students to choose the easy, low-learning route to a degree. For example, in one study, "the social multiplier for academic cheating is approximately three if a complete expansion of new cheaters begetting other new cheaters were to occur" (Carrell et al. 2008, p. 175). However, among 1,159 students surveyed in nine undergraduate universities in the UK, peer disapproval $(-0.062)$ and fraternity/sorority membership (0.070) were correlated much more strongly with cheating than peer behaviour (0.029) (McCabe \& Treviño 1997, p. 389). Similarly, among 73,738 students at US universities and 1,543 in Lebanon,

the perception of the behaviour of one's peers with regard to academic integrity showed a very strong relationship with a student's individual decision on whether to engage in academic integrity-reinforcing, in our minds, the importance of community (peer pressure) in promoting student integrity and reducing academic dishonesty (McCabe et al. 2012: KL1039).

These findings support Bowers' (1964, p. 196) earlier study of more than 5,000 students at 99 private and state universities in the US, which identified peer disapproval as "the most important determinant of changes in cheating behaviour between high school and college." In another survey involving 474 students, general embarrassment was 2.47 times more influential than friends' disapproval (a narrow concept) (Diekhoff et al. 1996, p. 499-500).

Given the influence of peer behaviour and disapproval, it is not surprising that, among 6,000 students surveyed at 31 universities, 66\% of those "at non-[honour]-code schools reported one or more transgressions on written work compared to $42 \%$ of ... [those] at code schools" (McCabe \& Treviño, 1996). Yet more dramatically, Brigham Young University introduced an honour code among 299 undergraduate sociology students and, within five years, cut cheating by 63\% (Canning 1956, p. 292).

To understand why honour codes reduce cheating, Miller et al. (2014, p. 169) surveyed 1,086 graduate and undergraduate students and found that those

who said they would not cheat because of punitive consequences were more likely to report that they cheated in classes and took less responsibility for promoting academic integrity [whereas] ... students whose reasons related to the value of learning, personal character, and/or it being simply not right reported less cheating and took more responsibility for academic integrity.

Further confirming the importance of the external environment and an individual's respect for professional ethics, another survey of 500 students at 28 universities found that "academic dishonesty was significantly correlated with: (1) the understanding/ acceptance of academic integrity policies...; (2) the perceived certainty of being reported ...; (3) the perceived severity of penalties ...; and (4) the perceptions of peers' behavior" (McCabe \& Treviño 1993, p. 53).

Responding to the need to create an ambience where ethical behaviour is embraced, promoted and adjudicated by the student body itself, some universities have adopted academic honour codes in order to create a proud ethical community with strong 
disapproval of fraudulent behaviour, as Ashesi University (s.d., p. 1) in Ghana accomplished under its "mission to educate a new generation of ethical leaders in Africa". An honour-code system is, however, hard to implement at large universities with many working and part-time students living in dispersed neighbourhoods. Nevertheless, though small honour-code universities achieve the best results, large universities significantly reduce academic fraud by adopting modified honour codes-a midway result strongly suggesting the impact of peer-group pressure favouring honest learning (McCabe \& Pavela 2000, p. 34).

\section{Preventive measures: to teach, influence or discipline?}

Students plagiarize due to ignorance, personal or peer-group pressures, values and practices, the opportunities presented, and the risks and consequences of getting caught. This diversity of internal and external influences upon students' decisions to plagiarize suggests the necessity of a holistic strategy by educational institutions to teach and encourage professional ethics and discourage academic fraud. Various technical, pedagogical, administrative, regulatory and, perhaps, legal measures can be taken to prevent or discourage plagiarism, all this together with efforts to build consensus among students, teachers and administrators about definitions, norms and the acceptance of individual and institutional responsibilities to make the system work. Then, when cases arise, teachers and administrators also need recognized structures and clear guidance to respond consistently while also respecting students' human rights.

\section{Early and ongoing prevention}

To reduce plagiarism, prevention is best. The primary focus should be on promoting writing and analytical skills, emphasizing the academic and economic benefits of proper techniques and good ethics, providing technological tools to train students to quote, reference and paraphrase properly, and establishing a private or public regulatory framework to ensure that universities, teachers and students cooperate and organize strategically on multiple fronts to prevent academic fraud, including plagiarism.

Administrators need to work with professors and students to build a strong, committed consensus that the academic goal of training original thinkers who have dignity and honour is good for students, universities and nations. Then, universities must teach new students about the necessity and techniques for properly referencing sources and provide instructional materials and referencing software so students and staff can clarify doubts and reduce errors. To eliminate the didactical confusion that arises when definitions and styles vary from professor to professor requires a consistent university-wide referencing policy that permits variations for specific disciplines (e.g., law, medicine, engineering) and, preferably, is reinforced by a sequence of writing skills courses or seminars during the degree course (Cleal 2005, p. 49; Ellery 2008, p. 513-14; Pecorari 2013: KL2358). Moreover, universities should firmly discourage (i) use of secondary sources when the primary sources are available and (ii) dependence on often unreliable sources such as Wikipedia and non-Ph.D. theses since these two practices are often signs of superficial research and poor professional judgment, frequently associated with plagiarism. To enforce this directive, a university might prohibit such practices unless a professor or supervisor grants an exemption due to the exceptional quality of the source. 
Buttressing this consensus and regulatory framework, lecturers need to emphasize the importance of good writing and correct referencing (Pecorari 2013:KL2358) and then be manifestly vigilant about plagiarism, a responsibility that many shirk, minify or reject. Wherever many lecturers have such negative attitudes, administrators face a substantial challenge to work with the academic community to build consensus about definitions, proper citation techniques, disciplinary regulations, and the urgent need for lecturers to promote professional ethics, help students to improve their writing and referencing skills, and cooperate with the disciplinary structures for cases of serious plagiarism. To train students and detect plagiarism more easily, lecturers need TSR software and, when reporting significant violations, merit administrative support. Moreover, due to "the strong association between past and future academic dishonesty, ... individuals who have participated in academic dishonesty are quite likely to offend again". Universities, therefore, need a computerized central registry for incidents of cheating handled by a teacher or adjudicated by the university (Williams \& Williams 2012, p. 106). The system should detect repetitive cheats and automatically inform the disciplinary structures (Devlin 2006, p. 50).

Universities should also mandate the publication of bachelor, masters and Ph.D. theses over the Internet, which is increasingly popular as more and more universities adhere to the Budapest Open Access Initiative for wide dissemination of peer-reviewed research results (Xia et al. 2012, p. 90; Weber-Wulff 2012, p. 33; BOAI Budapest Open Access Initiative 2002, BOAI 2012; Deutsche Nationalbibliothek 2009). Electronic publication facilitates public access and permits TSR software to scan uploaded theses as possible sources for plagiarized works. Though open-access publication may convince degree candidates that plagiarism is risky, it might threaten the economic interests of an author whose thesis presents potentially valuable discoveries, inventions or literary works. To safeguard such content, authors could be allowed to justify and request a temporary but renewable embargo on publication (Hawkins et al. 2013).

With exponential growth of the Internet, the ghost-writing of term papers, theses and dissertations became a burgeoning business threatening the credibility of the degrees issued by educational institutions where academic fraud is rife (Rooks 2006). To combat this, many US states have criminalized the direct or indirect sale of term papers, theses, dissertations or "other materials to be submitted for academic credit" (Berry 2010, p. 131-32). Some states permit universities "to request a court to enjoin a business from selling term papers, etc., to its students" (Standler 2012, p. 69). Despite many successful cases enjoining or closing down such companies, the laws and law suits have not halted the paper mills' popularity or profitability. Nevertheless, such laws comprise an important part of a holistic anti-plagiarism strategy (Dickerson 2007, p. 46).

Other legal or regulatory measures may also help in contexts where some higher education institutions are strong and others are new and academically weak. National regulation can require all higher education institutions to $(i)$ use TSR software to screen theses and, eventually, class papers, (ii) divulge theses on the Internet, and (iii) define and implement a holistic strategy against plagiarism and other academic fraud. ${ }^{\mathrm{d}}$ And, to thwart use of class papers from prior years or other nearby higher education institutions, TSR software should be permitted to retain copies in their databases.

Pedagogical changes can also be useful. For example, Kerkvliet and Sigmund (1999), p. 341) found that "students taught by faculty, rather than graduate teaching assistants 
(GTAs), were 32\% less likely to cheat. This is strong evidence that the use of GTAs is costly in terms of academic honesty". Also, the reuse of "old assessment tasks and topics makes it easy for students to plagiarise" from prior papers (Ford \& Hughes 2012, p. 184). Another "strategy is to avoid giving open-ended or generic topic assignments. Allowing students to write about any topic of their choosing ('pick some topic related to this course') or giving general topics ('write on a social concern') makes plagiarism appealing and easy" since online cheat sites provide thousands of papers on such topics (Rooks 2006, p. 4). Instead, professors should, when possible, assign projects involving field or laboratory research requiring original work thus reducing opportunities for plagiarism or, worse yet, the purchase of ready-made reports from "paper mills". As for theses, oral examination committees must be keenly aware of their two critical functions: (i) to determine the quality of the work and (ii) to use detailed questioning and, in seriously dubious cases, perhaps even the Cloze test to confirm that the work is, in fact, that of the degree candidate (McKelvie et al. 2004, p. 9; Rooks 2006, p. 6; Standing \& Gorassini 1986, p. 132).

Traditional or modified honour codes also yield measureable results though their implementation may encounter scepticism and resistance, especially from lecturers who lack honour-code experience (McCabe et al. 2003, p. 383). However, honour codes and shared governance make students partly responsible for dealing with cheating. This reduction represents "an important selling point to those non-code faculty who are reluctant to take on the unwanted responsibility of monitoring and policing student cheating" (McCabe et al. 2003, p. 383).

Resistance to honour codes and even to the entire effort to detect and discourage plagiarism may be intense if many of the lecturers graduated from institutions rife with academic fraud, as sometimes happens in countries with rapidly expanding university systems and many new, often small, and far from robust higher education institutions. In these conditions, some staff may feel personally threatened by proposals for a stricter code. To mitigate fears of possible denunciations and garner support may require an amnesty for past plagiarism while senior, highly published academics mount vigorous pedagogical efforts to ensure that all professors, teaching assistants and academics know the norms well. Thus, to confront such an academic crisis, the focus must be on the future, not the past.

\section{Detection and consequences}

Though, to reduce plagiarism, prevention must be primary, analysts generally agree that detection and remedial and disciplinary measures are also essential (Weber-Wulff 2014; Blum 2010; Pecorari 2006; McCabe et al. 2012). To detect plagiarism requires skills and technology complemented by clear agreed-upon administrative structures and regulations to guide professors confronting minor offences, and disciplinary committees judging serious cases. For example, how does one judge the seriousness of a case of plagiarism? What should the consequences be when deceptive intent is clearly present? Or when it is not? Teaching and minor reprimands seem best for new and junior students who are first or second offenders, with sterner measures reserved for senior and repeat offenders (Tennant \& Rowell 2010; Yeo \& Chien 2007). Definite consequences must also be mandated for plagiarism discovered in a thesis after the diploma is issued (Pavela 1999; Standler 2012). Moreover, when denouncing significant academic fraud, lecturers 
must be confident that their diligence is appreciated and appropriate disciplinary and pedagogical measures will ensue (Schmelkin et al. 2001, p. 6; Heckler et al. 2013, p. 244).

Detection measures and disciplinary consequences inspire proper practice and better learning. For example, in papers submitted by 664 students in one US university, $16.6 \%$ of the content was plagiarized if the use of TSR software not anticipated versus $9.8 \%$ after a warning (Heckler et al. 2013, p. 235). Similarly, among 569 internal and external business students at a New Zealand university, 31.4\% committed plagiarism before the warning, whereas, once forewarned, only $21 \%$ did so on the next assignment (Walker 2010, p. 9). Thus, vigilance, detection and punishment-taken together-buttress the educational and normative approaches to prevention. Toward that end, participation by student leaders in educational efforts to deter plagiarism and, later, in disciplinary hearings fortifies the desire by students to learn to cite correctly and avoid plagiarism.

\section{Conclusions}

Despite its pedagogical, ethical and long-term socio-economic implications, plagiarism is common among university students-worldwide. With multiple pressures and an ambience where cheating is common and detection and punishment, infrequent, many students deem plagiarism-or, more broadly, cheating-to be normal and of negligible ethical significance. Moreover, some universities provide little or no training about the seriousness of plagiarism and how to avoid it. Compounding the problem, many professors-though a minority-are far from diligent about detecting plagiarism and taking appropriate pedagogical or disciplinary measures as a serious signal to students.

Do Mozambican universities suffer such problems? The present examination of 150 licenciatura and MA theses from five large Mozambican universities revealed that $75 \%$ contained significant plagiarism. To counter this, universities can apply and experiment with the most efficacious measures for prevention (including writing courses, innovative course-assessment techniques, TSR software and modified honour systems with significant student leadership) and define and implement remedial and disciplinary actions appropriate for diverse cases.

TSR programs are, however, far from perfect. The programs, TurnItIn and Urkund, used to screen the theses missed significant tracts with similarities to other texts, sometimes even mistakenly reporting the absence of verifiable plagiarism. The programs are still not robust enough to allow an educational institution to rely on just one TSR program, especially for theses. Since, to detect plagiarism, the search engines need access to potential sources, all theses should be available online similar to the way libraries in the best universities traditionally make all theses available to the scientific community. Nevertheless, even if universities use such software, the situation is dynamic. To disguise the real sources, students and the numerous "paper mills" available on the Internet will increasingly translate or paraphrase from foreign-language texts or invent new technical ruses to trick detection programs into overlooking similarities. Camouflage versus detection: it is a digital race!

As TSR search engines become more flexible and thorough, educational institutions and even the law also need to adapt to combat plagiarism as a grave threat to educational quality and an ethical problem with significant socio-economic implications 
when students graduate as habitually dishonest or seriously incompetent "professionals". Sale or purchase of papers or theses for the purpose of academic fraud should also be criminalized. However, to avoid copyright issues, universities may have to permit authors to request significant delays before divulging potentially valuable materials.

\section{Endnotes}

${ }^{a}$ KL means "Kindle Location".

${ }^{\mathrm{b}} \mathrm{See}$, for example, Bennett (2005), Russouw (2005), Andrews et al. (2007), Teixeira (2011), Teixeira \& Rocha (2006), Teixeira \& Rocha (2010a).

${ }^{c}$ Universidade Eduardo Mondlane (UEM), Universidade Pedagógica (UP), (Instituto Superior de Ciência e Tecnologia de Moçambique (ISCTEM), Universidade São Tomás de Moçambique (USTM) and the Universidade Politécnica (UPol) [formerly the Instituto Superior Politécnico (ISPO)].

das proposed by the Anti-Plagiarism Regulation endorsed in April 2014 by Mozambique's National Council for Higher Education though not yet enacted into law.

\section{Acknowledgement}

This article is condensed from the full report by Coughlin (2014).

Received: 19 November 2014 Accepted: 13 March 2015

Published online: 30 June 2015

\section{References}

Andreescu L (2013) Self-plagiarism in academic publishing: The anatomy of a misnomer. Sci Eng Ethics 19:775-97 Andrews K, Smith L, Henzi D, Demps L. (2007). Faculty and student perceptions of academic integrity at U.S. and Canadian dental schools. Journal of Dental Education, 71(8), 1027-39

Ashesi University. s.d. Honour at Ashesi University College. Ashesi University College, Honour System White Paper. Retrieved from: http://ashesi.edu.gh/images/about/the\%20honour\%20system\%20at\%20ashesi\%20university\%20college\%20-\% 20white\%20paper.pdf

Coughlin P (2013) Tracer study on finalists and graduates of the Economic Policy Management Program for the masters degree: Professional relevance, acquired competencies, and gaps in the course of studies. Evaluation commissioned by the African Capacity Building Foundation and the Faculty of Economics, Eduardo Mondlane University

Coughlin P (2014) Plagiarism in five universities in Mozambique: Magnitude, detection techniques, and control measures-Full report. EconPolicy Research Group, Ltd., Maputo

Barrón-Cedeño A, Vila M, Martí M, Rosso P (2012) Plagiarism meets paraphrasing: Insights for the next generation in automatic plagiarism detection. Computational Linguistics 38(4):917-47, Retrieved from: http://www.mitpressjournals.org/doi/ pdfplus/10.1162/COLI_a_00153

Batane T (2010) Turning to Turnitin to fight plagiarism among university students. Journal of Educational Technology \& Society $13(2): 1-12$

Bennett R (2005) Factors associated with student plagiarism in a post-1992 university. Assessment \& Evaluation in Higher Education 30(2):137-62

Berry R (2010) Plagiarism: The legal landscape. Sacred Heart University, Library Faculty Publications. Paper 24. http:// digitalcommons.sacredheart.edu/cgi/viewcontent.cgi?article=1023\&context=library_staff

Blum S (2010) My word! Plagiarism and college culture. Cornell University Press, Ithaca, New York

BOAI (Budapest Open Access Initiative). (2002). Read the Budapest Open Access Initiative. Retrieved from: http://www.budapestopenaccessinitiative.org/read

BOAl. (2012) Ten years on from the Budapest Open Access Initiative: Setting the default to open. Retrieved from: http:// www.budapestopenaccessinitiative.org/boai-10-recommendations

Bowers W (1964) Student dishonesty and its control in college. Bureau of Applied Social Research, Columbia University, New York

Bretag, T, Mahmud, S (2009) A model for determining student plagiarism: Electronic. detection and academic judgement. Journal of University Teaching \& Learning Practice 6(1)

Canning R (1956) Does an honour code reduce classroom cheating? An experimental answer. Journal of Experimental Education 24(4):292-96

Carroll, J, Appleton, J (2005) Towards consistent penalty decisions for breaches of academic regulations in one UK university. International Journal for Educational Integrity, 1(1), Retrieved from: http://www.ojs.unisa.edu.au/index.php/ IJEl/article/view/15/5

Carrell S, Malmstrom F, West J (2008) Peer effects in academic cheating. J Hum Resour 43(1):173-207

Cleal J (2005) The role of referencing policy and advice in supporting undergraduate learners. Stud Learn Eval Innov Dev 2(2):49-55

Collberg C, Kobourov S (2005) Self-plagiarism in computer science. Commun ACM 48(4):88-95 
Deutsche Nationalbibliothek. (2009). Ablieferungspflicht von Dissertationen in körperlicher und/oder unkörperlicher Form. Retrieved from: http://www.dnb.de/SharedDocs/Downloads/DE/DNB/netzpub/ablieferungspflichtDissertationen.pdf? _ blob=publicationfile

Devlin M (2006) Policy, preparation, and prevention: Proactive minimization of student plagiarism. Journal of Higher Education Policy and Management 28(1):45-58. doi:10.1080/13600800500283791

Dickerson D (2007) Facilitated plagiarism: The saga of term-paper mills and the failure of legislation and litigation to control them. Villanova Law Review 52(1):21-46, Retrieved from: http://digitalcommons.law.villanova.edu/cgi/ viewcontent.cgi?article $=1131 \&$ context $=v \mid r$

Diekhoff G, LeBeff E, Clark R, Williams L, Francis B, Haines V (1996) College cheating: Ten years later. Res High Educ 37(4):487-50. doi:0361-0365/96/0800-0487509.50/0

Ellery K (2008) Undergraduate plagiarism: A pedagogical perspective. Assessment and Evaluation in Higher Education 33(5):507-16. doi:0361-0365/96/0800-0487509.50/0

European Science Foundation \& All European Academies (2011) The European Code of Conduct for Research Integrity. Ireq, Strasbourg, http://www.nsf.gov/od/oise/Code_Conduct_Researchlntegrity.pdf

Flint A, Clegg S, Macdonald R (2006) Exploring staff perceptions of student plagiarism. J Furth High Educ 30(2):145-56. doi:10.1080/03098770600617562

Ford P, Hughes C (2012) Academic integrity and plagiarism: Perceptions and experience of staff and students in a school of dentistry: A situational analysis of staff and student perspectives. Eur J Dent Educ 16:e180-e186. doi:10.1111/j.1600-0579.2011.00695.x

Gillam L, Marinuzzi J, Loannou P (2010) TurnltOff: Defeating plagiarism detection systems. 11th Annual Conference of the Subject Centre for Information and Computer Sciences, 24th-26th August, Durham University, pp 84-89, Retrieved from: http://citeseerx.ist.psu.edu/viewdoc/download?doi=10.1.1.174.2745\&rep=rep 1\&type=pdf\#page=87

Harvard College Writing Program. (2013). What constitutes plagiarism? In: Harvard Guide to Using Sources. http://isites.harvard.edu/icb/icb.do?keyword=k70847\&pageid=icb.page342054\#a_icb_pagecontent732741_mosaic

Hawkins A, Kimball M, Ives M (2013) Mandatory open access publishing for electronic theses and dissertations: Ethics and enthusiasm. Journal of Academic Librarianship 39:32-60

Heckler N, Rice M, Ryan H (2013) Turnitin systems: A deterrent to plagiarism in college classrooms. J Res Technol Educ 45(3):229-48

iThenicate (2012) True costs of academic misconduct. A 2012 iThenicate Report. Retrieved from: http://cdn2.hubspot.net/ hub/92785/file-5415630-pdf/docs/ithenticate-misconduct-report-2012.pdf

Jann B, Jerke J, Krumpal I (2012) Asking sensitive questions using the crosswise model: An experimental survey measuring plagiarism. Public Opin Q 76(1):32-49. doi:10.1093/poq/nfr036

Jendrek M (1989) Faculty reactions to academic dishonesty. J Coll Stud Dev 30(Sept.):401-406

Karlins M, Michaels C, Podlogar S (1988) An empirical example of actual cheating in a large sample of undergraduates. Res High Educ 29(4):359-64

Kerkvliet, J and Sigmund, C (1999) Can we control cheating in the classroom? Journal of Economic Education 30(4)

Lawson R (2004) Is classroom cheating related to business students' propensity to cheat in the "real world"? J Bus Ethics 49(2):331-43

Marsden H, Carroll M, Neill J (2005) Who cheats at university? A self-report study of dishonest academic behaviours in a sample of Australian university students. Aust J Psychol 57(1):1-10. doi:10.1080/00049530412331283426

McCabe D, Pavela G (2000) Some good news about academic integrity. Change 33(5):32-38. doi:10.1080/00091380009605738

McCabe, D, Treviño, L (1996) What we know about cheating in college. Change 28(1)

McCabe D, Treviño L (1993) Academic dishonesty: Honor codes and other contextual influences. J High Educ 64(3):522-38

McCabe D, Treviño L (1997) Individual and contextual influences on academic dishonesty: A multi-campus investigation. Res High Educ 38:378-401

McCabe D, Butterfield K, Treviño L (2003) Faculty and academic integrity: The influence of current honor codes and past honor code experiences. Res High Educ 44(3):367-85

McCabe D, Butterfield K, Treviño L (2006) Academic dishonesty in graduate business programs: Prevalence, causes, and proposed action. Academy of Management Learning \& Education 5(3):294-305, http:// faculty.mwsu.edu/psychology/dave.carlston/Writing\%20in\%20Psychology/Academic\%20Dishonesty/ Grop\%204/business2.pdf

McCabe D, Butterfield K, Treviño L (2012) Cheating in College: Why Students Do It and What Educators Can Do about It. John Hopkins Univ. Press. Kindle Edition, Baltimore

McCullough M, Holmberg M (2005) Using the Google search engine to detect word-for-word plagiarism in master's theses: A preliminary study. Coll Stud J 39:435-41

McKelvie S, Black S, Standing L (2004) Guide to academic honesty for the Department of Psychology (revised version, June 2004). Retrieved from: http://topix.teachpsych.org/f/Guide+to+Academic+Honesty+by+McKelvie+Standing+and + Black.pdf

Michalska, A (2012) Student plagiarism and national differences across Europe. Paper presented at the International Integrity \& Plagiarism Conference. Retrieved from: http://www. plagiarismadvice.org/research-papers/item/ differences-across-europe

Miller A, Shoptaugh C, Wooldridge J (2014) Reasons not to cheat: Academic-integrity responsibility, and frequency of cheating. Journal of Experimental Education 79:169-84. doi:10.1080/00220970903567830

Nejati M, Ismail S, Shafaei A (2011) Students' unethical behaviour: Insights from an African country. Global Business and Management Research 3(3 \& 4):276-95

Nonis S, Swift C (2001) An examination of the relationship between academic dishonesty and workplace dishonesty: A multicampus investigation. J Educ Bus 77(2):69-77

Paterson B, Taylor L, Usick B (2003) The construction of plagiarism in a school of nursing. Learn Health Soc Care 2(3):147-58

Pavela G (1999) For the same reasons that students can be expelled, degrees ought to be revocable. Chronicle of Higher Education: The Chronicle Review (October 22) 
Pecorari D (2006) Visible and occluded citation features in postgraduate second-language writing. Engl Specif Purp 25:4-29. doi:10.1016/j.esp.2005.04.004

Pecorari D (2013) Teaching to avoid plagiarism: How to promote good source use. Open University Press. Kindle edition, Maidenhead, Berkshire

Pincus H, Schmelkin L (2003) Faculty perceptions of academic dishonesty: A multidimensional scaling analysis. J High Educ 74(2):196-209

Pupovac V, Bilic-Zulle L, Mavrinac M, Petrovecki M (2010) Attitudes toward plagiarism among pharmacy and medical biochemistry students: Cross-sectional survey study. Biochemia Medica 20(3):307-13, doi:10.11613/BM.2010.039

Roig M (1997) Can undergraduate students determine whether text has been plagiarized? Psychol Rec 47(1):113-22

Roig M (2001) Plagiarism and paraphrasing criteria of college and university professors. Ethics and Behavior 11(3):307-23. doi:10.1207/S15327019EB1103_8

Rooks C (2006) [www.2cheat.com] update. Paper presented at the Summer Institute, Fresno City College. Retrieved from: http://files.eric.ed.gov/fulltext/ED502148.pdf

Russouw S (2005) Net closes on university cheats. IOL News, February 26. http://mobi.iol.co.za/\#!/article/net-closes-onuniversity-chats- 1.235023

Scanlon P, Neumann D (2002) Internet plagiarism among college students. J Coll Stud Dev 43(3):374-85

Schmelkin L, Kaufman A, Liebling D (2001) Faculty assessments of the clarity and prevalence of academic dishonesty. Paper presented at the Annual Meeting of the American Psychological Association, San Francisco, August 24-28. Retrieved from: http://files.eric.ed.gov/fulltext/ED459653.pdf

Selwyn N (2008) 'Not necessarily a bad thing ...': A study of online plagiarism amongst undergraduate students. Assessment \& Evaluation in Higher Education 33(5):465-79. doi:10.1080/02602930701563104

Sims R (1993) The relationship between academic dishonesty and unethical business practices. J Educ Bus 68(March/ April):207-11. doi:10.1080/08832323.1993.10117614

Standing L, Gorassini D (1986) An evaluation of the Cloze Procedure as a test for plagiarism. Teach Psychol 13(3):130-32

Standler R (2012) Plagiarism in colleges in USA: Legal aspects of plagiarism, academic policy. Retrieved from: http://www.rbs2.com/plag.pdf

Sutherland-Smith W (2003) Hiding in the shadows: Risks and dilemmas of plagiarism in student academic writing. In: Conference papers, abstracts and symposia, Australian Association for Research in Education, Coldstream, Vic., 1-18 http://dro.deakin.edu.au/eserv/DU:30005189/sutherlandsmith-hidingintheshadows-2003.pdf

Teixeira C (2011) Integridade académica em Portugal: Relatório síntese global do estudo. Faculdade de Economia, Universidade do Porto. Retrieved from: http://www.wwwords.co.uk/pdf/validate.asp?j=rcie\&vol=1\&issue=3\&year= 2006\&article=1_Teixeira_RCIE_1_3_web

Teixeira C, Rocha M (2006) Academic cheating in Austria, Portugal, Romania and Spain: A comparative analysis. Res Comp Int Educ 1(3):198-209, Retrieved from: http://www.wwwords.co.uk/pdf/ validate.asp?j=rcie\&vol=1\&issue $=3 \&$ year=2006\&article=1_Teixeira_RCIE_1_3_web

Teixeira A, Rocha M (2010a) Academic misconduct in Portugal: Results from a large scale survey to university economics/business students. Journal of Academic Ethics 8(1):21-41. doi:10.1007/s10805-010-9102-3

Teixeira A, Rocha M (2010b) Cheating by economics and business undergraduate students: An exploratory international assessment. High Educ 59(6):663-71. doi:10.1007/s10734-009-9274-1

Tennant P, Rowell R (2010) Benchmark Plagiarism Tariff: A benchmark tariff for the application of penalties for student plagiarism in higher education. Report by iParadigms Europe Ltd. http://www.plagiarismadvice.org/resources/ institutional-approaches/item/tennant-benchmarkreport

Todd-Mancillas W, McEuen V, Sisson E (1987) Academic dishonesty among communication students and professionals: Some consequences and what might be done about them. Annual Meeting of the Speech Communication Association, Boston. http://englishprofessionals.net/wp-content/uploads/2011/11/academic-dishonesty-1.pdf

Turn|tIn. (2013?) The plagiarism spectrum: Instructor insights into the 10 types of plagiarism. White Paper for Turnlt|n. Retrieved from: http://go.turnitin.com/paper/plagiarism-spectrum

Walker J (2010) Measuring plagiarism: Researching what students do, not what they say they do. Stud High Educ 35(1):41-59. doi:10.1080/03075070902912994

Weber-Wulff D (2012) Plagiarism policies in Germany. PowerPoint presentation at the Hochschule für Technik und Wirtschaft, Berlin, Retrieved from: http://www.plagiat.pl/cms_pdf/prezentacja\%20prof.\%20dr\%20Debora\%20WeberWulff\%20-\%20Plagiarism\%20Policies\%20in\%20Germany.pdf

Weber-Wulff D (2014) False feathers: A perspective on academic plagiarism. Springer, New York

Weber-Wulff D, Möller C, Touras J, Zincke E (2013) Plagiarism detection software test 2013. http://plagiat.htw-berlin.de/ software-en/test2013/report-2013

Williams M, Williams M (2012) Academic dishonesty, self-control, and general criminality: A prospective and retrospective study of academic dishonesty in a New Zealand university. Ethics \& Behavior 22(2):89-112. doi:10.1080/10508422.2011.653291

Yeo S, Chien R (2007) Evaluation of a process and pro forma for making consistent decisions about the seriousness of plagiarism incidents. Qual High Educ 13(2):187-204. doi:10.1080/13538320701629202

Xia J, Gilchrist S, Smith N, Kingery J, Radecki J, Wilhelm M, Mahn A (2012) A review of open access self-archiving mandate policies. Libr Acad 20(2):85-102 